\title{
Hyperlipidemia is Associated with Altered Levels of Insulin-Like Growth Factor-I
}

\author{
J. MALÍK, T. ŠTULC, D. WICHTERLE ${ }^{1}$, V. MELENOVSKÝ ${ }^{1}$, E. CHYTILOVÁ, \\ Z. LACINOVÁ, J. MAREK, R. ČEŠKA
}

Third Department of Internal Medicine, General University Hospital and First Faculty of Medicine, Charles University, Prague, ${ }^{1}$ Institute for Clinical and Experimental Medicine, Cardiology Division, Prague, Czech Republic

Received May 7, 2007

Accepted September 11, 2007

On-line November 30, 2007

\begin{abstract}
Summary
Previous studies revealed altered levels of the circulating insulinlike growth factor-I (IGF-I) and of its binding protein-3 (IGFBP-3) in subjects with coronary atherosclerosis, metabolic syndrome and premature atherosclerosis. Hyperlipidemia is a powerful risk factor of atherosclerosis. We expected IGF-I and IGFBP-3 alterations in subjects with moderate/severe hyperlipidemia but without any clinical manifestation of atherosclerosis. Total IGF-I and IGFBP-3 were assessed in 56 patients with mixed hyperlipidemia ( $\mathrm{MHL}$; cholesterol $>6.0 \mathrm{mmol} / \mathrm{l}$, triglycerides $>2.0 \mathrm{mmol} / \mathrm{l}$ ), in 33 patients with isolated hypercholesterolemia (IHC; cholesterol $>6.0 \mathrm{mmol} / \mathrm{l}$, triglycerides $<2.0 \mathrm{mmol} / \mathrm{l}$ ), and in 29 healthy controls (cholesterol $<6.0 \mathrm{mmol} / \mathrm{l}$, triglycerides $<2.0 \mathrm{mmol} / \mathrm{l}$ ). The molar ratio of IGF-I/IGFBP-3 was used as a measure of free IGF-I. IHC subjects differed from controls by lower total IGF-I (164 \pm 60 vs. $209 \pm 73 \mathrm{ng} / \mathrm{ml}, \mathrm{p}=0.01)$ and IGF-I /IGFBP-3 ratio $(0.14 \pm 0.05$ vs. $0.17 \pm 0.04, p=0.04)$. Compared to controls, MHL subjects had lower total IGF-I $(153 \pm 54 \mathrm{ng} / \mathrm{ml}, \mathrm{p}=0.0002)$ and IGFBP-3 $(2.8 \pm 0.6$ $\mathrm{mg} / \mathrm{ml}, \mathrm{p}<0.0001)$, but higher IGF-I/IGFBP-3 ratio $(0.25 \pm 0.06$, $\mathrm{p}<0.0001$ ). Differences remained significant after the adjustment for clinical and biochemical covariates, except for triglycerides. Patients with both IHC and MHL have lower total IGF-I compared to controls. The mechanism is presumably different in IHC and MHL. Because of prominent reduction of IGFBP-3 in patients with $\mathrm{MHL}$, they have reduced total IGF-I despite the actual elevation IGF-I/IGFBP-3 ratio as a surrogate of free IGF-I.
\end{abstract}

\section{Key words}

Atherosclerosis • Growth factors • Insulin resistance • Cholesterol • Metabolic syndrome

\section{Corresponding author}

J. Malík, Third Department of Internal Medicine, General University Hospital, U nemocnice 1, 12808 Prague 2, Czech Republic. Tel/fax: +420 224923 852. E-mail: malik.jan@vfn.cz

\section{Introduction}

Insulin-like growth factor-I (IGF-I), produced in many tissues, has both local (paracrine) and circulating (systemic) pool, and affects growth and differentiation of cells. It is engaged in the regulation of glucose homeostasis and protein metabolism. Circulating IGF-I originates mainly in the liver and is controlled by pituitary growth hormone (GH). Biological availability of IGF-I is strongly influenced by specific binding proteins (IGFBPs). IGFBP-3 carries more than $80 \%$ of circulating pool of IGF-1 and is also under control of GH (Baxter 1994). IGF-I circulates mainly in the $150 \mathrm{kDa}$ ternary complexes comprising of one molecule each of IGF, IGFBP-3 and the acid-labile subunit (ALS). The latter prolongs IGF-I half-life and prevents its penetration through the endothelium (Boisclair et al. 2001).

Serum IGF-I and IGFBP-3 levels decline during adulthood and are involved in physiological changes of aging (Ceda et al. 1998). Moreover, circulating IGF-I seems to be an indicator of two leading causes of mortality in western countries: while higher concentrations have been linked to cancers (Ma et al. 1999), lower levels were found to be associated with cardiovascular diseases (Spalarossa et al. 1996, SchulerLuttmann et al. 2000, Juul et al. 2002, Vasan et al. 2003, Laughlin et al. 2004). The association between IGF-I and atherosclerosis is also supported by experimental research (Tsukahara et al. 1994). The reports on the relationship between IGF-I and serum lipids are controversial. Discrepant correlations between total IGF-I and low- 
density lipoprotein (LDL) cholesterol were observed in three studies ((Prewitt et al. 1992, Ceda et al. 1998, Laughlin et al. 2004). However, GH replacement therapy (Svensson et al. 2002) and IGF-I administration to diabetic subjects (Pratipanawatr et al. 2001) resulted in a decline in serum cholesterol and triglycerides. IGF-I and IGFBP-3 have not been studied in subjects with moderate/severe hyperlipidemia, who are at substantial cardiovascular risk. Inclusion of these subjects would help to recognize the relation between lipids and IGFI/IGFBP system.

Two common hyperlipidemia phenotypes isolated hypercholesterolemia and mixed hyperlipidemia are associated with different metabolic changes. The latter is usually combined with impaired glucose tolerance (Sandhu et al. 2002). We therefore expected that subjects with moderate/severe hyperlipidemia will have reduced total IGF-I and that the type of hyperlipidemia will affect this reduction. Therefore, we compared total IGF-I in patients with isolated hypercholesterolemia (IHC) or mixed hyperlipidemia (MHL) to those in normolipidemic healthy controls. In order to estimate the free fraction of IGF-I, we also analyzed IGFBP-3 in all subjects.

\section{Subjects and Methods}

We investigated two groups of hyperlipidemic subjects and a group of healthy controls. Hyperlipidemic subjects were consecutively recruited from patients referred to university hospital based lipid clinic who agreed with the participation in this study. All study subjects were free of clinically manifest vascular disease and did not take any lipid lowering medication for at least 2 months. Patients with secondary hyperlipidemia, alcohol abuse, diabetes mellitus, malignancy, malnutrition or endocrine disorders were excluded. The first group consisted of subjects with mixed hyperlipidemia (MHL group) defined by total cholesterol $>6.0 \mathrm{mmol} / 1$ and triglycerides $>2.0 \mathrm{mmol} / \mathrm{l}$. Subject with apo E2/E2 genotype or with lipoprotein lipase deficiency were not included. The second group included subjects with isolated hypercholesterolemia (IHC group) defined by total cholesterol $>6.0 \mathrm{mmol} / \mathrm{l}$ and triglycerides $<2.0$ mmol/1. All participants underwent at least two serum lipid analysis prior to the inclusion into this study to ensure correct classification of hyperlipidemic subjects (pre-inclusion values are not shown). The control group consisted of non-obese normolipidemic healthy subjects (total cholesterol $<6.0 \mathrm{mmol} / \mathrm{l}$ and triglycerides $<2.0 \mathrm{mmol} / \mathrm{l}$ ).

The local Ethical Committee approved the design of the study and all participants signed informed consent. The study conformed to the principles outlined in the Declaration of Helsinki.

\section{Biochemical analyses}

The blood samples were drawn in the mornings after $12 \mathrm{~h}$ fasting. Serum levels of both IGF-I and IGFBP-3 were measured with an immunoradiometric assay (ImmunoTech, France). Total IGF-I was analyzed after serum extraction with acid ethanol to release IGF-I bound to IGFBPs as described previously (Justová et al. 2001). Intra-assay coefficient of variation declared by the manufacturer was 2.9-7.4\% for IGF-I measurement (depending on concentration) and $3.9 \%$ for IGFBP-3. Inter-assay coefficient of variation was 8.9-15.5\% for IGF-I (depending of concentration) and 1.8-3.9\% for IGFBP-3. Serum insulin was also determined by immunoradiometric assay (CIS Bio International, France). Serum total and HDL-cholesterol, triglycerides, and glucose were measured using automated analyzer methods; LDL-cholesterol was calculated according to Friedewald's formula (data are available only in subjects with triglyceride level below $4.5 \mathrm{mmol} / \mathrm{l}$ ).

\section{Statistical methods}

All variables were expressed as mean \pm S.D. with the following two exceptions. Triglyceride and insulin concentrations were logarithmically transformed prior to the analysis in order to normalize their distribution and are expressed as median (range). Molar ratio of IGF-I / IGFBP-3 was used as a measure of free IGF-I. Differences between groups were analyzed by two-tailed t-test for independent samples and by an analysis of covariance (ANCOVA) to adjust for appropriate covariates (age, body mass index - BMI, total cholesterol, HDL-cholesterol, LDL-cholesterol, triglycerides and insulin). Inter-related variables (such as total and LDL cholesterol) were included into the analysis separately. $\mathrm{P}<0.05$ values were considered as significant.

Univariate correlation analysis was performed separately for each group and then for all subjects together. IGF-I, IGFBP-3 and IGF-I/IGFBP-3 ratio were correlated with age, BMI, total-, LDL- and HDLcholesterol, triglycerides, insulin and glycemia. LDLcholesterol was adjusted only in the comparison of IHC 
to controls, because in MHL it was available only in 15 cases. $\mathrm{P}<0.05$ value was considered as significant in between groups analysis. For intra-group correlation analyses, the significance level (p) was lowered to $<0.01$, and for merged groups analysis to $<0.001$ to prevent multiple testing bias.

\section{Results}

A total of 118 subjects were enrolled: 33, 56, and 29 into IHC, MHL, and control groups, respectively. One outlying non-physiological value of IGF-I in the control group was excluded from the analysis $(496 \mathrm{ng} / \mathrm{ml})$ together with IGF-I/IGFBP-3 ratio. These exclusions did not change the significance of performed analyses. Baseline characteristics of studied groups are summarized in Table 1.

Differences in total IGF-I, IGFBP-3, and IGF-I/ IGFBP-3 ratio between hyperlipidemic patients and controls are shown in Table 2. Both patient groups had significantly lower total IGF-I compared to controls. This difference was more pronounced in MHL patients. As IHC patients had no change in IGFBP-3, decrease of total IGF-I was associated with significant reduction of free IGF-I fraction. On the other hand, we observed a pronounced decrease of IGFBP-3 in patients with MHL accompanied by a highly significant increase in free IGFI compared to controls

The differences in IGF-I and IGF-I/IGFBP-3 ratio in IHC compared to controls were adjusted for age, total cholesterol, LDL-cholesterol and triglycerides, i.e. variables that significantly differed in these two groups. Differences of both IGF-I and IGFBP-3 remained significant also after this adjustment.

IGF-I difference between MHC and controls remained significant after the adjustment for age, BMI, total cholesterol, HDL-cholesterol and insulin, but significance disappeared after adding triglycerides. The difference in IGF-I/IGFBP-3 ratio remained significant after the adjustment for age, BMI, total or HDLcholesterol, but disappeared after adding triglycerides or insulin. IGFBP-3 difference remained significant even after the adjustment for all aforementioned variables.

In IHC group, we observed significant correlation between IGFBP-3 and total cholesterol $(\mathrm{r}=0.47, \mathrm{p}<0.01)$. In MHL group, significant correlations were the following: IGF-I vs. age $(\mathrm{r}=-0.52, \mathrm{p}<0.0001)$, IGF-I/IGFBP-3 ratio vs. age $(\mathrm{r}=-0.51, \mathrm{p}<0.01)$. In control group, a significant correlation was only for IGF-I
Table 1. Baseline characteristics of groups.

\begin{tabular}{|c|c|c|c|}
\hline & $\begin{array}{l}\text { Controls } \\
(n=29)\end{array}$ & $\begin{array}{c}\text { IHC } \\
(n=33)\end{array}$ & $\begin{array}{c}\text { MHL } \\
(n=56)\end{array}$ \\
\hline Age (years) & $47 \pm 6$ & $53 \pm 10^{*}$ & $49 \pm 10$ \\
\hline Males/females & $10 / 19$ & $11 / 22$ & $12 / 44$ \\
\hline$B M I\left(\mathrm{~kg} / \mathrm{m}^{2}\right)$ & $25.1 \pm 3.2$ & $26.6 \pm 4.0$ & $28.4 \pm 3.7^{\dagger}$ \\
\hline $\begin{array}{l}\text { Total } \\
\text { cholesterol } \\
(\mathrm{mmol} / \mathrm{l})\end{array}$ & $5.1 \pm 0.2$ & $8.4 \pm 1.6^{\ddagger}$ & $7.5 \pm 1.5^{\ddagger}$ \\
\hline LDL ( $\mathrm{mmol} / \mathrm{l})$ & $3.0 \pm 0.6$ & $5.8 \pm 1.6^{*}$ & $4.4 \pm 1.1^{*}$ \\
\hline HDL $(\mathrm{mmol} / \mathrm{l})$ & $1.6 \pm 0.3$ & $1.6 \pm 0.3$ & $1.2 \pm 0.3^{\ddagger}$ \\
\hline $\begin{array}{l}\text { Triglycerides } \\
(\mathrm{mmol} / \mathrm{l})\end{array}$ & $0.9(2.4)$ & $1.6(2.6)^{\dagger}$ & $3.8(17.7)^{*}$ \\
\hline $\begin{array}{l}\text { Glycemia } \\
\text { (mmol/l) }\end{array}$ & $5.1 \pm 0.6$ & $5.2 \pm 0.6$ & $5.4 \pm 0.7$ \\
\hline Insulin $(m U / l)$ & $4.5(37)$ & $4.0(17.2)$ & $22.2(68.2)^{*}$ \\
\hline
\end{tabular}

Values shown as mean \pm S.D. or median (quartile range). Difference versus controls: $* p<0.05,+p<0.001, \neq p<10^{-6}$. IHC: isolated hypercholesterolemia; MHL: mixed hyperlipidemia; BMI: body mass index.

vs. age $(r=0.39, p=0.04)$. Correlations in merged groups are shown in Table 3.

\section{Discussion}

We found that hyperlipidemic subjects have significantly lower total IGF-I compared to controls. While in IHC patients the production of IGF-I might really be reduced, in MHL patients, the production of IGF-I is probably increased and low IGFBP-3 is responsible for the total IGF-I reduction. IGF-I/IGFBP-3 ratio was decreased in $\mathrm{IHC}$, but increased in MHL.

The ratio of IGF-I/IGFBP-3 was used as a measure of free IGF-I, similarly as in many other studies (Spalarossa et al. 1996, Schuler-Luttmann et al. 2000, Juul et al. 2002, Vasan et al. 2003, Laughlin et al. 2004). Free IGF-I could be directly measured by radioimmunoanalysis or by ultrafiltration. Ultrafiltration method is very laborious and technically demanding, while the other method is extremely time-dependent during the incubation, which could easily lead to overestimation of real free IGF-I level. Furthermore, it is practically impossible to separate free IGF-I from that bound to IGFBPs, and this is why some authors argue against direct assessment of free IGF-I. However, it does not fully mirror the complexity of interactions between 
Table 2. Differences in IGF-related indices between controls and patients with hyperlipidemia.

\begin{tabular}{|c|c|c|c|c|c|}
\hline & \multirow{2}{*}{$\frac{\text { Controls }}{\text { mean } \pm \text { S.D. }}$} & \multicolumn{2}{|c|}{ IHC } & \multicolumn{2}{|c|}{ MHL } \\
\hline & & mean \pm S.D. & $\mathrm{P}$ value & mean \pm S.D. & $\mathrm{P}$ value \\
\hline $\begin{array}{l}\text { Total IGF-I } \\
(\mathrm{ng} / \mathrm{ml})\end{array}$ & $196 \pm 43$ & $167 \pm 63$ & 0.045 & $152 \pm 54$ & 0.0004 \\
\hline$I G F B P-3(\mathrm{mg} / \mathrm{ml})$ & $4.3 \pm 0.9$ & $4.6 \pm 1.1$ & 0.20 & $2.8 \pm 0.9$ & $<10^{-9}$ \\
\hline $\begin{array}{l}I G F-I / I G F B P-3 \\
\text { ratio }\end{array}$ & $0.17 \pm 0.04$ & $0.14 \pm 0.05$ & 0.03 & $0.24 \pm 0.06$ & 0.00003 \\
\hline
\end{tabular}

IHC: isolated hypercholesterolemia; MHL: mixed hyperlipidemia; IGF-I: insulin-like growth factor-I; IGFBP-3: insulin-like growth factor binding protein-3; IGF-I/IGFBP-3: their molar ratio, which provides a measure of free IGF-I; $\mathrm{p}$ (ANCOVA): $\mathrm{p}$ value after adjustment for age, gender, body mass index, total cholesterol, and triglycerides.

Table 3. Correlation analysis - merged groups.

\begin{tabular}{lcccccccc}
\hline & Age & BMI & $\begin{array}{c}\text { Total } \\
\text { cholesterol }\end{array}$ & Triglycerides & $\begin{array}{c}\text { HDL- } \\
\text { cholesterol }\end{array}$ & $\begin{array}{c}\text { LDL- } \\
\text { cholesterol }\end{array}$ & Insulin & Glucose \\
\hline IGF-I & $-0.60^{*}$ & -0.16 & -0.13 & -0.08 & 0.14 & 0.00 & -0.09 & -0.23 \\
IGFBP-3 & -0.02 & -0.10 & 0.05 & $-0.42^{*}$ & 0.33 & 0.25 & $-0.57^{*}$ & -0.14 \\
IGF-I/IGFBP-3 ratio & $-0.41^{*}$ & 0.06 & -0.03 & $0.37^{*}$ & -0.36 & -0.19 & $0.63^{*}$ & -0.03 \\
\hline
\end{tabular}

Subjects from all 3 groups were merged together for the purpose of this analysis. IGF-I: insulin-like growth factor-I; IGFBP-3: insulinlike growth factor binding protein-3; IGF-I/IGFBP-3: their molar ratio, which provides a measure of free IGF-I; BMI: body mass index. $* \mathrm{p}<0.001$

IGF-I, its binding proteins and ALS. IGF-I/IGFBP-3 ratio is reliable only in some conditions, such as acromegaly, GH deficiency etc. (Frystyk 2004). If there is a direct effect of IGF-I on the development of atherosclerosis, investigation of free IGF-I fraction is crucial. Unfortunately, there are minimal data on the association of free IGF-I with cardiovascular disease. Janssen et al. (1998) documented that low free IGF-I is associated with an increased risk of atherosclerosis in an elderly population. In another study (van der Beld et al. 2003), an inverse relation between carotid intima/media thickness and free (but not total) IGF-I was observed.

The inverse relationship between both total and LDL cholesterol and total IGF-I was originally observed in slightly hypercholesterolemic women (Prewitt et al. 1992). In a subsequent smaller study, total IGF-I was also inversely related to LDL-cholesterol (Ceda et al. 1998). In larger trials, this association was either neutral (Juul et al. 2002) or slightly positive (Laughlin et al. 2004). Positive correlation of total IGF-I with HDL-cholesterol and apolipoprotein A1 was reported (Ceda et al. 1998). Recent population studies found inverse relationships between total IGF-I and the extent of angiographically documented coronary atherosclerosis in men $<70$ years (SchulerLuttmann et al. 2000). It was also shown that low total IGF-I significantly and independently increases the risk for subsequent ischemic heart disease (Juul et al. 2002), increases the cardiovascular mortality among elderly men and women (Laughlin et al. 2004), and is associated with the risk for the development of type-2 diabetes mellitus (Sandhu et al. 2002). The epidemiological studies did not specifically address the relationship between IGF-I and serum lipids. It was only observed that cardiovascular risk attributed to IGF-I was weaker after the adjustment for serum lipids (Juul and Gyllenborg 2003).

Our present and previous data (Malík et al. 2003) data suggest that the poorer prognosis of patients with reduced total IGF-I might partly result from the association with hyperlipidemia, which represents a significant risk factor itself. It is plausible to speculate that the mechanism, which underlies the reduction of total IGF-I, is different in IHC and MHL patients.

In patients with IHC, we observed similar levels of IGFBP-3 as in controls. Therefore, the reduction of IGF- 
I/IGFBP-3 ratio in IHC patients cannot be explained by the change of IGF-binding capacity. Interestingly, in our preliminary study (Malík et al. 2003), IGFBP-3 was positively related to total cholesterol and IGFBP-3 levels were even significantly higher in hypercholesterolemic subjects. These findings may explain reduced free IGF-I, but not the total IGF-I decrease in IHC. There are only few studies which have examined the connection between cholesterol metabolism and GH/IGF-I axis. It was shown that both GH and IGF-I stimulate the density of hepatic LDL receptors (Rudling et al. 1992) and increase macrophage uptake and degradation of LDL (Hochberg et al. 1992). It was also reported that while native LDL increases the synthesis of IGF-I, oxidized LDL decreases production of both IGF-I and the IGF-I receptor (Scheidegger et al. 2000). In summary, the biological mechanism for decreased level of IGF in IHC remains elusive.

It should be emphasized that the MHL group differed from healthy controls not only by lipids, but also by other features of metabolic syndrome. Therefore, besides lipids, also other factors probably played a role in observed differences in IGF1 and IGFBP-3. In this group, we observed significantly lower IGFBP-3 than in controls. This difference was more pronounced than that of total IGF-I. Since IGFBP-3 carries more than $80 \%$ of circulating IGF-I, this observation leads to a hypothesis that IGFBP-3 reduction is the primary, if not the only cause of total IGF-I lowering in MHL patients. Indeed, increased proteolysis of IGFBP-3 was observed in insulin resistance (Bang et al. 1994) that typically coexists with MHL. We can speculate that the proteolysis of IGFBP-3 might be a physiological mechanism of free IGF-I increase, because the main regulator of IGF-I, growth hormone, stimulates the liver production of not only IGF-I but also of IGFBP-3. On the other hand, presuming that only free IGF-I is a biologically active substance, the reduction of IGFBP-3 alone cannot explain the increase of free IGF-I. It may be that the increase of free IGF-I in MHL patients reflects an "IGF-I resistant" condition that parallels the hyperinsulinemia due to insulin resistance. Indeed, IGF-I and insulin have similar roles in glucose homeostasis, although they act through different receptors (Pratipanawatr et al. 2001, Sandhu et al. 2002). Of course, IGF-I/IGFBP-3 ratio is not the same as free IGF-I, but similar results as in our study were also reported by Ricart and Fernandez-Real (2001), who examined obese subjects with metabolic syndrome. The concept of IGF-I resistance was introduced by Pratipanawatr et al. (2001), who performed euglycemic IGF-I clamp. They found that in type 2 diabetic patients, the ability of IGF-I to augment total body glucose disposal and to suppress plasma free fatty acid concentration is impaired, indicating that both muscle and fat tissues are resistant to the action of IGF-I. In contrast, IGF-I keeps the ability to suppress hepatic glucose production also in diabetic subjects. Central IGF-I receptors are probably sensitive in insulin-resistant subjects as suggested by the following studies. Although the decrease of $\mathrm{GH}$ production was observed in obese subjects (Vahl et al. 1997), the responsiveness to external GH was high (Gleeson et al. 2005). Recombinant human IGF-I treatment of genetic forms of severe insulinresistance resulted in increased insulin sensitivity (Moses et al. 1995). We could also speculate that the increase of free IGF-I in MHL is a natural mechanism to improve insulin sensitivity. Indeed, increased levels of portal insulin suppress hepatic production of another IGF-I binding protein, IGFBP-1 (not analyzed in this study) (Janssen et al. 1998). Furthermore, insulin per se increases liver synthesis of IGF-I in vitro (Schnetzler et al. 1991). We performed a post hoc selection of subjects with metabolic syndrome (according to ATPIII definition) from the MHL group and obtained similar results regarding to IGF-I, IGFBP-3 and IGF-I/IGFBP-3 ratio as in the whole MHL group. Such findings should, however, be confirmed in another study, where metabolic syndrome (and not only MHL), should be the primary inclusion criterion.

\section{Limitations}

A general limitation of this and similar studies is that it is not possible to distinguish between effects of IGFI and GH. These effects are counteracting in some aspects, such as in glucose regulation. Measurement of $\mathrm{GH}$ production is technically difficult due to large intra-day fluctuations of its level. Another limitation of these clinical studies is the inability to compare relative effects of ALS and of all binding proteins. However, the fact that IGFBP3 binds over $80 \%$ of serum IGF-I somewhat justifies this simplification.

\section{Conclusions}

This study demonstrates that hyperlipidemic patients have lower total IGF-I than normolipidemic subjects. The mechanism is presumably different in IHC and MHL. Because of a prominent reduction in IGFBP-3 in patients with MHL, they have reduced total IGF-I despite the actual elevation of IGF-I/IGFBP-3 ratio as a 
possible surrogate of free IGF-I. This finding emphasizes the importance of clinical research focused on the role of free IGF-I in atherogenesis. An increase of free IGF-I in MHL patients may reflect an endogenous mechanism to improve insulin sensitivity and/or an "IGF-I resistant" condition that parallels the hyperinsulinemia of insulin resistance. The study suggests that differences in both IGF-I and its binding protein may represent an independent trait of patients with metabolic syndrome.

\section{Conflict of Interest}

There is no conflict of interest.

\section{Acknowledgements}

The study was supported by the Research Project MSM0021620807 of Ministry of Education, Czech Republic.

\section{References}

BANG P, BRISMAR K, ROSENFELD RG: Increased proteolysis of insulin-like growth factor binding protein-3 (IGFBP-3) in noninsulin-dependent diabetes mellitus serum with elevation of a 29-kilodalton (kDa) glycosylated IGFBP-3 fragment contained in the approximately 130 - to $150 \mathrm{kDa}$ ternary complex. $J$ Clin Endocrinol Metab 78: 1119-1127, 1994.

BAXTER RC: Insulin-like growth factor binding proteins in the human circulation: a review. Horm Res 42: 140-144, 1994.

BOISCLAIR YR, RHOADS RP, UEKI I, WANG J, OOI GT: The acid-labile subunit (ALS) of the $150 \mathrm{kDa}$ IGFbinding protein complex: an important but forgotten component of the circulating IGF system. $J$ Endocrinol 170: $63-70,2001$.

CEDA GP, DALl'AGLiO E, MAGNACAVALlO A, VARGAS N, FONTANA V, MAGGIO M, VALENTI G, LEE PD, HINTZ RL, HOFFMAN AR: The insulin-like growth factor axis and plasma lipid levels in the elderly. J Clin Endocrinol Metab 83: 499-502, 1998.

FRYSTYK J: Free insulin-like growth factors - measurements and relationships to growth hormone secretion and glucose homeostasis. Groth Horm IGF Res. 14: 337-375, 2004.

GLEESON HK, LISSETT CA, SHALET SM: IGF-I response to a single bolus of growth hormone is increased in obesity. J Clin Endocrinol Metab 90: 1061-1067, 2005.

HOCHBERG Z, HERTZ P, MAOR G, OIKNINE J, AVIRAM M: Growth hormone and insulin-like growth factor-I increase macrophage uptake and degranulation of low density lipoprotein. Endocrinology 131: 430-435, 1992.

JANSSEN JA, STOLK RP, POLS HA, GROBBEE DE, LAMBERTS SW: Serum total IGF-I, free IGF-I, and IGFBP-1 levels in an elderly population: relation to cardiovascular risk factors and disease. Arterioscler Thromb Vasc Biol 18: 277-282, 1998.

JUSTOVÁ V, LACINOVÁ Z, MELENOVSKÝ V, MAREK J, HOLLY JMP, HAAS T: The changes of IGF binding proteins after rhGH administration to patients totally dependent on parenteral nutrition. Growth Horm IGF Res 11: 407-415, 2001.

JUUL A, GYLLENBORG J: Unravelling Reaven's syndrome X: serum insulin-like growth factor-I and cardiovascular disease. Circulation 107:190e-192e, 2003.

JUUL A, SCHEIKE T, DAVIDSEN M, GYLLENBORG J, JORGENSEN T: Low serum insulin-like growth factor I is associated with increased risk of ischemic heart disease. Circulation 106: 939-944, 2002.

LAUGHLIN GA, BARRETT-CONNOR E, CRIQUI M, KRITZ-SILVERSTEIN D: The prospective association of serum insulin-like growth factor I (IGF I) and IGF-binding protein-1 levels with all cause and cardiovascular disease mortality in older adults: The Rancho Bernardo Study. J Clin Endocrinol Metab 89: 114-120, 2004.

MA J, POLLAK MN, GIOVANNUCCI E, CHAN JM, TAO Y, HENNEKENS CH, STAMPFER MJ: Prospective study of colorectal cancer risk in men and plasma levels of insulin-like growth factor (IGF)-I and IGF-binding protein-3. J Natl Cancer Inst 91: 620-625, 1999.

MALÍK J, ŠTULC T, ČEŠKA R: Unraveling Reaven's syndrome X: serum insulin-like growth factor-I and cardiovascular disease. Circulation 107: e190-e192, 2003. 
MOSES AC, LORROW LA, O'BRIEN M, MOLLER D, FLIER JS: Insulin-like growth factor I (rhIGF-I) as a therapeutic agent for hyperinsulinemic insulin-resistant diabetes mellitus. Diabetes Res Clin Pract 28: S185S194, 1995.

PRATIPANAWATR T, PRATIPANAWATR W, ROSEN C, ROSEN C, BERRIA R, BAJAJ M, CUSI K, MANDARINO L, KASHYAP S, BELFORT R, DEFRONZO RA: Effect of IGF-I on FFA and glucose metabolism in control and type 2 diabetic subjects. Am J Physiol 282: E1360-E1368, 2001.

PREWITT TE, UNTERMAN TG, GLICK TG, COLE TG, SCHMEISSER D, BOWEN PE, LANGENBERG P: Insulin-like growth factor I and low-density-lipoprotein cholesterol in women during high- and low-fat feeding. Am J Clin Nutr 55: 381-384, 1992.

RICART W, FERNANDEZ-REAL JM: No decrease in free IGF-I with increasing insulin in obesity-related insulin resistance. Obes Res 9: 631-636, 2001.

RUDLING M, NORSTEDT G, OLIVECRONA H, REIHNER E, GUSTAFSSON J, ANGELIN B: Importance of growth hormone for the induction of hepatic low density lipoprotein receptors. Proc Natl Acad Sci USA 89: 6983-6987, 1992.

SANDHU MS, HEALD AH, GIBSON JM, CRUICKSHANK JK, DUNGER DB, WAREHAM NJ: Circulating concentrations of insulin-like growth factor-I and development of glucose intolerance. a prospective observational study. Lancet 359: 1740-1745, 2002.

SCHEIDEGGER KJ, JAMES RW, DE LA FONTAINE P: Differential effects of low density lipoproteins on insulin-like growth factor-I (IGF-I) and IGF-I receptor expression in vascular, smooth muscle cells. J Biol Chem 275 : 26864-26869, 2000.

SCHNETZLER MB, SCHMID C, MEIER PJ, FROESCH ER: Insulin regulates insulin-like growth factor I mRNA in rat hepatocytes. Am J Physiol 260: E846-E851, 1991.

SCHULER-LUTTMANN S, MONNIG G, ENBERGS A, SCHULTE H, BREITHARDT G, ASSMANN G, KERBER S, VON ECKARDSTEIN A: Insulin-like growth factor-binding protein-3 is associated with the presence and extent of coronary arteriosclerosis. Arterioscler Thromb Vasc Biol 20: e10-e15, 2000.

SPALLAROSSA P, BRUNELLI C, MINUTO F, CARUSO D, BATTISTINI M, CAPONNETTO S, CORDERA R: Insulin-like growth factor-I and angiographically documented coronary artery disease. Am J Cardiol 77: 200202, 1996.

SVENSSON J, FOWELIN J, LANDIN K, BENGTSSON BA, JOHANSSON JO: Effects of seven years of GHreplacement therapy on insulin sensitivity in GH-deficient adults. J Clin Endocrinol Metab 87: 2121-2127, 2002.

VASAN RS, SULLIVAN LM, D’AGOSTINO RB, ROUBENOFF R, HARRIS T, SAWYER DB, LEVY D, WILSON PW: Serum insulin-like growth factor I and risk for heart failure in elderly individuals without a previous myocardial infarction: The Framingham Heart Study. Arch Intern Med 139: 642-648, 2003.

TSUKAHARA H, GORDIENKO DV, TONSHOFF B, GELATO MC, GOLIGORSKY MS: Direct demonstration of insulin-like growth factor-I induced nitric oxide by endothelial cells. Kidney Int 45: 598-604, 1994.

VAN DER BELD AW, BOTS ML, JANSSEN JA, POLS HA, LAMBERTS SW, GROBBEE DE: Endogenous hormones and carotid atherosclerosis in elderly men. Am J Epidemiol 157: 25-31, 2003.

VAHL N, JORGENSEN JO, SKJAERBAEK C, VELDHUIS JD, ORSKOV H, CHRISTIANSEN JS: Abdominal adiposity rather than age and sex predicts mass and regularity of GH secretion in healthy adults. Am J Physiol 272: E1108-E1116, 1997. 